\title{
Microsatellite variation in Australian and Indonesian pearl oyster Pinctada maxima populations
}

\author{
J. A. H. Benzie ${ }^{1,2}$, C. Smith-Keune $e^{1,3, *}$ \\ ${ }^{1}$ Australian Institute of Marine Science, PMB No. 3, Townsville , Queensland 4810, Australia \\ ${ }^{2}$ Centre for Marine and Coastal Studies, The University of New South Wales, Sydney, New South Wales 2052, Australia \\ ${ }^{3}$ Aquaculture Department, James Cook University, Townsville, Queensland 4811, Australia
}

\begin{abstract}
Eight microsatellite markers were used to screen over 1700 individual pearl oysters Pinctada maxima from 5 Western Australian (Lacepedes, 80 Mile Beach Shallow, 80 Mile Beach Deep, Port Hedland and Exmouth Gulf), 1 northern Australian (Darwin) and 2 Indonesian (Madura and Sumbawa) populations. There was a strong and highly significant relationship between the amount of genetic divergence between pairs of populations and their degree of geographical separation. Within Australia, there was some indication for genetic differences between Exmouth Gulf and the other Western Australian populations and also between Darwin and the Western Australian populations. The Indonesian populations were significantly different from all Australian populations, suggesting little or no direct recruitment to Western Australia from Indonesian sources. Comparison of 2 year-classes of spat $(0+$ and $1+)$ in some Australian populations showed no evidence of differences among Western Australian sites. Comparison of the same recruitment class at 2 different ages (0+ spat in 1998 and $1+$ spat in 1999) provided no evidence for selection at the screened, or closely linked, loci. With the possible exception of Exmouth Gulf, Western Australian populations can be considered 1 stock with a large effective population size (no $<300$ and more likely several 1000s).
\end{abstract}

KEY WORDS: Biogeography $\cdot$ Fisheries management $\cdot$ Indo-Pacific $\cdot$ Microsatellite DNA $\cdot$ Pearl oyster $\cdot$ Pinctada maxima $\cdot$ Population genetics $\cdot$ Recruitment

\section{INTRODUCTION}

The recruitment of marine species is highly variable in space and time (Caffey 1985, Connell \& Keough 1985, Menge 1991). Lack of knowledge about the sources of recruits and the factors that affect temporal changes in recruitment are major impediments to understanding the dynamics of marine populations. The genetic structure of populations is influenced by the source of recruits, fluctuations in the number of adults providing young to the next generation, and selection on larval and immediate post-settlement phases of species with mixed life cycles (Hedgecock et al. 1992, Lenfant \& Planes 2002). The application of genetics has promise, therefore, in understanding the source(s) and temporal variation in recruitment in marine species and enabling more effective management of marine resources (Taylor \& Dizon 1996). Molecular genetics has been used successfully to determine different stocks in fisheries and to identify the sources of fish in mixed feeding groups (Ryman \& Utter 1987). Fluctuations in gene frequencies from year-class to year-class have been described for a number of mollusc species, and have been used to infer large variance in reproductive success or selection at early phases of the life cycle (Johnson \& Black 1984, Hedgecock et al. 1992). The stability of gene frequencies within populations that differ in gene frequencies from site to site has been used to suggest self-recruitment to those sites (e.g. in the queen scallop Aequipecten ventriculosis [Lewis \& Thorpe 1994] or Chlamys islandica [Galand \& Fevolden 2000]), and genetic adaptation to 
some sites has been indicated in the catarina scallop Argopecten ventricosus (Cruz et al. 1998).

Interpretation of the genetic structure of mollusc populations is difficult, due to the frequent occurrence of significant heterozygote deficits (Berger 1983). It was initially suggested that heterozygous individuals had better survival and faster growth (Zouros \& Foltz 1984). This may be the result of either direct effects at specific loci (the over-dominance hypothesis) or indirect effects as a result of linkage between markers and fitness-related traits (the associative over-dominance hypothesis), as reviewed in Zouros \& Pogson (1994). Subsequent work has shown considerable variation among species, with some studies showing no relationship between growth or survival and heterozygosity (Volckaert \& Zouros 1989, Fevolden 1992) and others showing a strong effect (Krause \& Bricelj 1995). Careful studies now available have suggested that positive relationships between heterozygosity and growth vary among annual cohorts and arise from inbreeding effects and associative over-dominance in Spisula ovalis (David et al. 1995, 1997a, David \& Jarne 1997) and in Crassotrea gigas (Thunberg, 1793) (McGoldrick \& Hedgecock 1997). The heterozygote deficits observed in wild populations, therefore, reflect variance in reproductive success leading to inbreeding, differential selection against genotypes (McGoldrick \& Hedgecock 1997), or mixing of populations that differ in their gene frequencies or spawning times (Rios et al. 1996), i.e. the Wahlund effect. Patchy patterns in age structure as well as spatial patterns in genetic structure in $S$. ovalis appear to reflect density-independent effects, such as spatial variation in larval supply, passive transport of juveniles, or predation on recruits rather than the density-dependent negative effects of adult density on settlement success (David et al. 1997b,c).

Pearl oysters are a group of bivalve molluscs that are widespread in the shallow tropical and subtropical seas, and a number of species in several genera are used to grow pearls (Shirai 1994). The commercially valuable silver lipped pearl oyster Pinctada maxima (Jameson, 1901) has a patchy distribution where a suitable mix of soft and hard substrate occurs. P. maxima, which occurs from the Indo-West Pacific to Indonesia and Western Australia, has a larval life of around $3 \mathrm{wk}$ (Gervis \& Sims 1992). In Western Australia, spat fall is measured annually by fishery managers, and is used to plan the take of wild shell in future years. Using allozymes, Johnson \& Joll (1993) showed that 2 widely separated $P$. maxima populations within Western Australia were not genetically differentiated. Larval dispersal was assumed to be effective over 100s of kilometers in that region, and the population was thought to be essentially panmictic. However, reductions in the recruitment levels of $P$. maxima in Western Australia in the late 1990s, and differences in recruitment between locations (e.g. Exmouth Gulf showed greater reductions than other locations) raised questions concerning the source of recruits to different Western Australian populations and their effective population size.

Allozymes have shown genetic divergence between Pinctada fucata (Gould, 1850), Pinctada albina (Lamarck, 1819) and Pinctada maculata (Gould, 1850) populations in Japan, between sites $<100 \mathrm{~km}$ apart (Wada 1982). Small genetic differences have been reported between widespread populations of Pinctada margaritifera (Linnaeus, 1758) in French Polynesia (Durand \& Blanc 1986, 1989), and significant differences were observed between geographically closer populations of $P$. margaritifera in the South Pacific (Benzie \& Ballment 1994). Beaumont \& Khamdan (1991) found substantial independence of local populations of Pinctada radiata (Leach, 1814) in Bahrain, where significant differentiation was observed between samples obtained from sites $<33 \mathrm{~km}$ apart. Johnson \& Joll (1993) also detected significant genetic differences among northern and eastern populations of $P$. maxima in Australia. In some cases, these populations were separated by as little as $320 \mathrm{~km}$ (Flat Top Bank and Oxley Island in the Northern Territory). More recently, DNA-based studies have shown marked and informative differences between patterns of genetic variation derived from nuclear and mtDNA data. For example, Arnaud et al. (2001) demonstrated isolation by distance between populations of $P$. mazatlanica (Gould, 1850) along the western American coast. This pattern was more strongly observed in mtDNA data, and suggested a recent and southward step-by-step colonization of that part of the species' range (Arnaud et al. 2003a). P. margaratifera populations from the South Pacific showed some divergence between archipelagos, and more limited mtDNA variation than nuclear divergence was attributed to recent colonization of many atolls after the last low sea level stand (Arnaud et al. 2003b). These data suggest that pearl oyster species may show marked genetic distinctions between populations at a variety of spatial scales, using a variety of genetic markers.

Johnson \& Joll (1993) examined only 2 Pinctada maxima populations in Western Australia using allozymes. Analysis of a greater number of populations using highly variable microsatellite DNA might provide more detailed information on genetic variation in wild P. maxima stocks in Western Australia. Further analysis of juveniles and spat may provide a clearer signal of recruitment from particular sources. These signals might not be detected in an adult population that was the result of a mixture of recruitment events occurring over several years. This paper reports the 
analysis of spatial and temporal variation in microsatellite allele frequencies in populations of Western Australian $P$. maxima. The study was designed to assess the source of recruits, the number of adults contributing to the next generation, and whether selection occurred after settlement. Collections from Indonesia and northern Australia allowed larger scale connectivity and 2 potential long-distance sources of recruits to be assessed.

\section{MATERIALS AND METHODS}

Sample collection. A total of 1737 Pinctada maxima samples were collected from 6 populations in Australia and 2 in Indonesia (Fig. 1). Details of the sites and sample sizes are given in Table 1. Samples were collected from Australian populations in 1998, and consisted of animals from 3 different year-classes defined by dorso-ventral shell length, $0+$ spat (1 to $60 \mathrm{~mm}), 1+$ spat (61 to $120 \mathrm{~mm}$ ) and adults (>120 mm). In 1999 a second set of $0+$ and $1+$ spat were collected from the Lacepede Islands, 80 Mile Beach, Port Hedland and Exmouth Gulf, to allow a comparison of gene frequencies for a single cohort over 2 successive years. The 2 Indonesian populations were collected in November 1999. Initially 2 sites were collected in each of 80 Mile Shallow and 80 Mile Deep populations. The 80 Mile Shallow collections were made almost continuously between 10 and 18 miles south of the northern tip of 80 Mile Beach and were fused into 1 sample. The 80 Mile Deep collections were made from Cape Bossut and Compass Rose sites, the latter being more offshore than the former. These 2 sites showed no significant microsatellite frequency differences and were also fused.

Samples of both adductor muscle and mantle tissue were collected from Pinctada maxima oysters of various sizes aboard pearling industry vessels in Western Australia. Whole shell samples from the Indonesian sites were delivered by road to Gondol Fisheries Station and held in flowing seawater tanks prior to dissection. The entire soft tissues from small spat were removed from the shell. Samples were either snap frozen in liquid nitrogen or preserved in $70 \%$ ethanol immediately following collection.

Table 1. Pinctada maxima. Sample numbers for each year-class collected at each location. Adults from Australia were collected in 1998, those from Indonesia in 1999. Collections within Australia were made in 2 states, the Northern Territory (NT) and Western Australia (WA). Variation from these sample numbers may occur in Appendices 1 to 3, because not all individuals could be amplified for every locus

\begin{tabular}{|lrrrrrrr|}
\hline Location & \multicolumn{2}{c}{ 0+ spat } & \multicolumn{2}{c}{ 1+ spat } & Adults & Total \\
& 1998 & 1999 & 1998 & 1999 & & \\
\hline Sumbawa, Indonesia & 0 & 0 & 0 & 0 & 50 & 50 \\
Madura, Indonesia & 0 & 0 & 0 & 0 & 50 & 50 \\
Darwin, NT & 3 & 0 & 60 & 0 & 101 & 164 \\
Lacepede Islands, WA & 19 & 0 & 88 & 50 & 100 & 257 \\
80 Mile Beach, Deep, WA & 7 & 0 & 81 & 0 & 87 & 175 \\
80 Mile Beach, Shallow, WA & 88 & 32 & 100 & 98 & 100 & 418 \\
Port Hedland, WA & 28 & 7 & 50 & 88 & 73 & 246 \\
Exmouth Gulf, WA & 52 & 2 & 100 & 123 & 100 & 377 \\
Total & 197 & 41 & 479 & 359 & 661 & 1737 \\
\hline
\end{tabular}


RNase A to a final concentration of $0.1 \mathrm{mg} \mathrm{ml}^{-1}$ with a $1 \mathrm{~h}$ incubation at $37^{\circ} \mathrm{C}$. DNA was then extracted and precipitated using standard phenol:chloroform:isoamyl alcohol methods as per Sambrook et al. (1989). Best results were achieved with adductor muscle tissue from adult or sub-adult oysters (>60 mm dorsoventral shell length, DVL) that had been snap frozen in liquid nitrogen. Although DNA extraction was possible from smaller animals, this had to be from mixed tissues due to the small size of the oysters, and problems were often encountered when trying to amplify DNA from juvenile oysters (<60 mm DVL). Samples of adductor muscle from adult oysters preserved in $70 \%$ ethanol were also readily amplifiable, although the extracted DNA was more degraded than that from snap frozen samples. Extraction from mantle tissue resulted in co-precipitation of pigmented compounds that often prevented PCR (polymerase chain reaction) amplification.

The microsatellites screened were the 8 polymorphic loci (Pmx + 008, Pmx + 014, Pmx 18_21, Pmx +020, Pmx +022, Pmx 16_05, Pmx 16_41 and Pmx 16_23) that had been isolated and characterized from genomic DNA libraries constructed by pooling DNA from 3 Pinctada maxima oysters and optimized for fluorescent PCR as described in Smith et al. (2003). PCR cycling conditions and reaction conditions followed those described by these authors. Genescan data from each fragment analysis run was imported into Genotyper software (ABI) for automated scoring of alleles. PCR products were labeled on the basis of size, and positive controls (clones containing the sequenced allele) were run on each gel to check for variation between gel runs. Tables of PCR product sizes were generated for each individual at all loci prior to conversion of PCR product sizes to 2 digit allele codes for analysis with GENEPOP 3.3 software (Raymond \& Rousset 1995).

Data on the sequence of a number of alleles has also been reported, and showed that size anomalies exhibited by 3 loci (Pmx 16_23, Pmx + 020 and Pmx 18_21) are explained by $\geq 1$ insertion/deletion event(s) (indels) identified in the flanking sequence outside these microsatellite markers (Smith et al. 2003). PCR product sizes were corrected to that of a condition with no deletions (i.e. the scored size was increased by the number of bases in the deletion) so that PCR products of different lengths but the same number of repeat units were coded as a single allele. GENEPOP analysis was performed both with and without the size-corrected data, and, as correction for indels did not alter the conclusions of the analysis, only the results from sizecorrected data are given in the present paper. Sequencing of multiple alleles of a 4 th compound tetra/di-nucleotide locus (Pmx +008) showed that there was variation in repeat number both within the di-nucleotide and tetra-nucleotide microsatellite regions, producing mixtures of alleles unable to be distinguished on the basis of the size of the PCR product. PCR product sizes accurately reflected variation within the microsatellite region in the other 5 loci $(\mathrm{Pmx}+008$, Pmx +014, Pmx 16_05, Pmx 16_41 and Pmx + 022). In these latter cases DNA sequencing of $\geq 5$ different alleles per locus confirmed that PCR product sizes were consistent with simple increases or decreases in the number of microsatellite repeat units (Smith et al. 2003).

Statistical analyses. Markov chain approximations of unbiased estimates of exact tests were used to determine the probabilities that loci deviated significantly from Hardy-Weinberg equilibrium, as implemented in the program GENEPOP 3.3 (Raymond \& Rousset 1995). Fisher's method was used to assess genotypic disequilibrium by determining $p$-values for each locus pair across all populations. Significance levels were corrected for all simultaneous multiple tests using the Bonferroni method (Rice 1989).

The probability of null alleles and their frequency were assessed for all adult populations using MicroChecker software 2.2.1 (van Oosterhout et al. 2004) and Brookfield's Number 2 null allele estimate (Brookfield 1996). Null allele estimates were not performed on juvenile age groups, due to the high failure rate of PCR and the resulting small sample sizes when individuals that failed for $\geq 3$ loci were excluded from the dataset.

Weir \& Cockerham's (1984) weighted analysis of variance was used to partition the genetic variation into that occurring within $\left(F_{\mathrm{IS}}\right)$ and among populations $\left(F_{\mathrm{ST}}\right)$. A multi-locus estimate of the correlation of allele size among populations $\left(R_{\mathrm{ST}}\right)$ was also obtained (Slatkin 1995). The significance of the $F_{\mathrm{ST}}$ and $R_{\mathrm{ST}}$ values was evaluated by performing $(\geq 1000)$ Monte-Carlo permutations of alleles across populations using ARLEQUIN V. 2.00 (Schneider et al. 2000). ARLEQUIN was also used to perform hierarchical analysis of population structure (AMOVA, analysis of molecular variation; Excoffier et al. 1992) and to calculate the Mantel test statistic $(Z)$ (Mantel 1967) to measure the degree of association between the matrix of pairwise $F_{\mathrm{ST}}$ comparisons and the geographic distance between populations. Estimates of gene flow were made assuming a stepping stone model of gene flow, because a strong pattern of isolation by distance was detected, using the equations: $N_{\mathrm{e}} m=\left(\left[1-F_{\mathrm{ST}}\right][-\ln 2 \mu]\right) / 4 \pi F_{\mathrm{ST}}$ or $N_{\mathrm{e}} m=([1-$ $\left.\left.R_{\mathrm{ST}}\right][-\ln 2 \mu]\right) / 4 \pi R_{\mathrm{ST}}$, where $N_{\mathrm{e}} m$ is the average number of migrants per generation and $\mu$ is the mutation rate assumed here to be $10^{-4}$ (Crow \& Aoki 1982, 1984). This estimate of $N_{\mathrm{e}} m$ differs from that of the island model by a constant value of $(-\ln 2 \mu) / \pi$ (Crow \& Aoki $1982,1984)$, which in this case equals 2.71. $N_{\mathrm{e}} m$ was 
also calculated separately using Slatkin's rare allele method as implemented in GENEPOP 3.1d.

Long-term effective population size estimates can be based on allelic diversity and mutation rates, particularly if population substructure is weak (Waples 1991); Crow \& Kimura's (1970) mutation-drift equilibrium equation $\left[4 N_{\mathrm{e}} \mu=H_{\mathrm{e}} /\left(1-H_{\mathrm{e}}\right)\right]$ was used to estimate the parameter. The infinite allele model of microsatellite evolution was used to estimate the product of the effective population size and the mutation rate per generation $\left(4 N_{\mathrm{e}} \mu\right)$. Microsatellite locus mutation rates range from $10^{-3}$ to $10^{-5}$ gamete $^{-1}$ generation $^{-1}$ (Weber \& Wong 1993); an average mutation rate of $10^{-4}$ was assumed for the 8 microsatellite loci used in this study.

Variance in allele frequencies over time can also be used to estimate effective population size over shorter time scales, and there were adequate samples to compare 1+ spat collected in 1998 to 1+ spat collected in 1999 for 4 populations: Lacepedes, 80 Mile Shallow, Port Hedland and Exmouth. The equations used followed those given in Pollak (1983), and all 8 microsatellite loci were used.

\section{RESULTS}

\section{Genetic diversity within populations}

There was a high degree of genetic diversity within each of the populations surveyed, with usually far more than $50 \%$ of the alleles observed in the total dataset recorded in any 1 population of adults, 1+ spat, or $0+$ spat (Appendices 1 to 3 in MEPS Supplementary Material at www.int-res.com/articles/suppl/m314p197_ app.pdf). Expected heterozygosities were high ( $>0.7)$ in nearly all populations for all loci, and most observed heterozygosities were not significantly lower than expected with exception of $\mathrm{Pmx}+014$ and $\mathrm{Pmx}+020$ in most populations of adults, $1+$ and $0+$ spat. Lower than expected heterozygosities were also seen at other loci in 1 or 2 populations, but the identity of the loci varied between populations and between year-classes. Populations of 1+ spat collected in 1999 showed heterozygote excesses in the Port Hedland population at Pmx 16_05 and Pmx 16_41 (Appendix 2).

Analysis of adult populations using MicroChecker provided no evidence for null alleles at Pmx+022 or Pmx+008. Limited evidence for null alleles was found in 4 populations at Pmx16_05 (mean null frequency 0.066, range 0.062 to 0.071), 4 populations at Pmx16_23 (mean frequency 0.164, range 0.084 to 0.309 ) and only 1 population at Pmx18_21 (frequency 0.098). Evidence of null alleles was found in all adult populations for the 2 loci Pmx+014 and Pmx+020. The range in frequency of these putative null alleles across all populations was small $(\mathrm{Pmx}+014$, mean frequency 0.229 , range 0.181 to 0.253; Pmx+020, mean frequency 0.224, range 0.214 to 0.307 ), and even smaller when considering only the Australian populations $(\mathrm{Pmx}+014$, range 0.221 to 0.259 ; Pmx+020, range 0.214 to 0.252 ). In any case, the distribution of the putative null alleles at these loci was not different from the patterns of variation of other alleles.

\section{Population differentiation}

The frequency distributions of alleles at each locus were similar among all populations within Western Australian and those within Indonesia. Populations within these broad locations were pooled to compare microsatellite frequency distributions in adult populations between 3 regions (Fig. 2). Frequency distributions varied between loci and were broadly similar among the 3 geographical regions, with exception of the Pmx 16_23 locus. This showed a high number of small-sized alleles in Western Australia that was not seen in other areas. There were more subtle differences in the frequency distributions at other loci. For example, the Indonesian populations had a relatively flat distribution for Pmx +014 , with a small peak at Allele 19 and above, while both the Northern Territory and Western Australia showed a distribution weighted towards the middle of the allele size range and peaking near Alleles 13 to 15. Subtle differences could also be seen at the Pmx +020, Pmx +022, Pmx 16_05 and Pmx 16_41 loci (Fig. 2).

Pairwise $F_{\mathrm{ST}}$ values between Darwin and the other Australian populations were almost an order of magnitude greater than those between Western Australian populations, and those between Indonesian populations and Western Australian ones were greater again by a factor of 2 (Table 2). The pairwise $F_{\text {ST }}$ values between Indonesian and all Australian populations and those between Darwin and the Western Australian populations were statistically significant, as were those comparisons of Exmouth with all other Western Australian populations. With exception of the 80 Mile Shallow population compared with the Lacepedes population none of the differences among the other Western Australian populations was significant. The $F_{\text {ST }}$ analyses reflected the number of loci that demonstrated statistically significant differences between population pairs after correcting for multiple simultaneous tests (Table 2).

A similar pattern was observed for the 1+ spat collected in 1998, the only year for which samples were obtained from all 6 Australian populations (Table 2). Pairwise $F_{\mathrm{ST}}$ values between Darwin and the Western Australian populations were approximately 5 times 

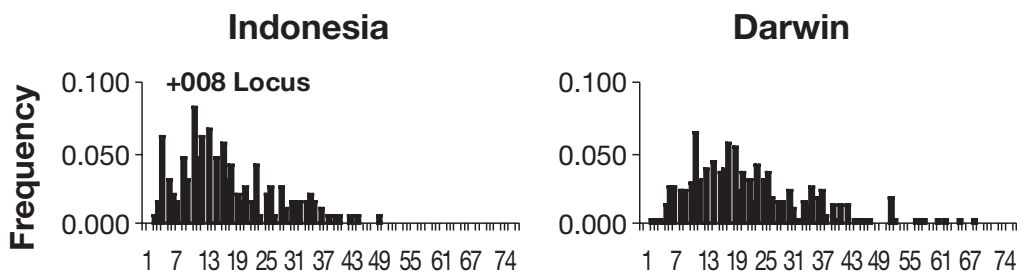

Western Australia
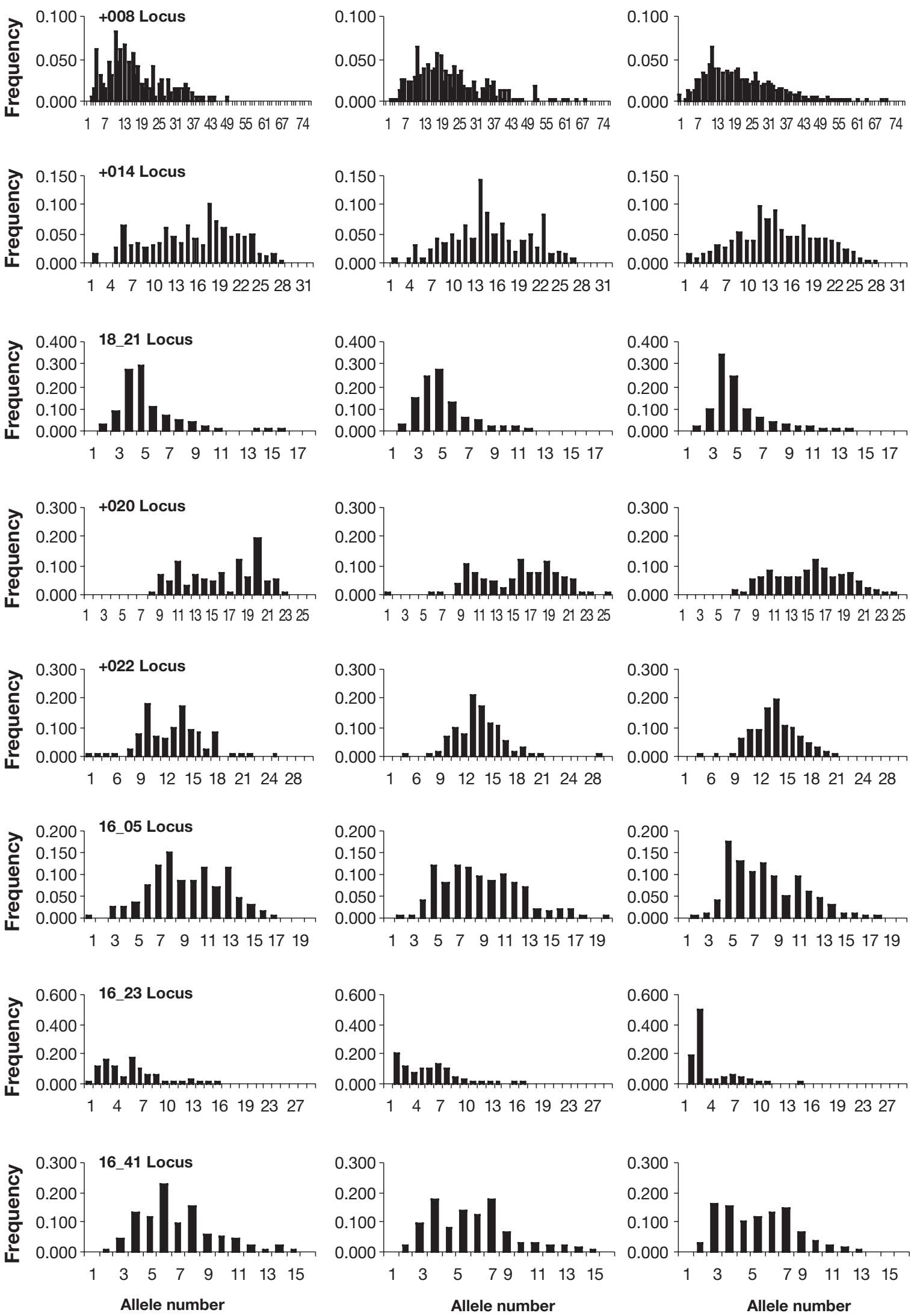

Fig. 2. Pinctada maxima. Frequency distributions of alleles at each microsatellite locus in adult populations from Indonesia, Darwin, and Western Australia 
Table 2. Pinctada maxima. Genetic differentiation between pairs of populations. Estimates of $F_{\mathrm{ST}}$ over all loci are given below the diagonal, and the number of loci in which significant differences in allele frequencies were detected is given above the diagonal. Significant values of $F_{\mathrm{ST}}$ after Bonferroni correction (Rice 1989) are given in bold. NT: Northern Territory; WA: Western Australia

\begin{tabular}{|c|c|c|c|c|c|c|c|c|}
\hline & \multicolumn{2}{|c|}{ Indonesia } & \multirow{2}{*}{$\begin{array}{c}\text { Australia, NT } \\
\text { Darwin }\end{array}$} & \multirow[b]{2}{*}{ Lacepedes } & \multirow[b]{2}{*}{$\begin{array}{l}80 \text { Mile } \\
\text { Deep }\end{array}$} & \multirow{2}{*}{$\begin{array}{c}\text { Australia, WA } \\
80 \text { Mile } \\
\text { Shallow }\end{array}$} & \multirow[b]{2}{*}{$\begin{array}{c}\text { Port } \\
\text { Hedland }\end{array}$} & \multirow[b]{2}{*}{ Exmouth } \\
\hline & Madura & Sumbawa & & & & & & \\
\hline \multicolumn{9}{|l|}{ Adults } \\
\hline Madura & - & 0 & 3 & 4 & 4 & 3 & 3 & 3 \\
\hline Sumbawa & -0.0006 & - & 3 & 4 & 5 & 6 & 4 & 6 \\
\hline Darwin & 0.0047 & 0.0099 & - & 4 & 2 & 3 & 2 & 3 \\
\hline Lacepedes & 0.0101 & 0.0130 & 0.0072 & - & 1 & 1 & 1 & 2 \\
\hline 80 Mile Deep & 0.0142 & 0.0155 & 0.0103 & 0.0014 & - & 0 & 0 & 1 \\
\hline 80 Mile Shallow & 0.0179 & 0.0204 & 0.0159 & 0.0034 & -0.0005 & - & 1 & 2 \\
\hline Port Hedland & 0.0114 & 0.0134 & 0.0078 & 0.0003 & -0.0015 & 0.0016 & - & 2 \\
\hline Exmouth & 0.0257 & 0.0288 & 0.0236 & 0.0063 & 0.0034 & 0.0024 & 0.0068 & - \\
\hline \multicolumn{9}{|l|}{$1+$ spat 1998} \\
\hline Darwin & - & - & - & 1 & 2 & 1 & 1 & 2 \\
\hline Lacepedes & - & - & 0.0108 & - & 0 & 0 & 1 & 1 \\
\hline 80 Mile Deep & - & - & 0.0149 & 0.0002 & - & 1 & 1 & 1 \\
\hline 80 Mile Shallow & - & - & 0.0158 & 0.0017 & 0.0028 & - & 1 & 1 \\
\hline Port Hedland & - & - & 0.0110 & 0.0022 & 0.0065 & 0.0018 & - & 0 \\
\hline Exmouth & - & - & 0.0266 & 0.0037 & 0.0032 & 0.0019 & 0.0062 & - \\
\hline \multicolumn{9}{|l|}{$0+$ spat 1998} \\
\hline Lacepedes & - & - & - & - & - & 4 & 0 & 2 \\
\hline 80 Mile Shallow & - & - & - & 0.0177 & - & - & 1 & 6 \\
\hline Port Hedland & - & - & - & 0.0115 & - & 0.0258 & - & 4 \\
\hline Exmouth & - & - & - & 0.0107 & - & 0.0383 & 0.0632 & - \\
\hline \multicolumn{9}{|l|}{$1+$ spat 1999} \\
\hline Lacepedes & - & - & - & - & - & 1 & 2 & 3 \\
\hline 80 Mile Shallow & - & - & - & 0.0024 & - & - & 2 & 1 \\
\hline Port Hedland & - & - & - & 0.0109 & - & 0.0019 & - & 2 \\
\hline Exmouth & - & - & - & 0.0120 & - & 0.0031 & 0.0023 & - \\
\hline
\end{tabular}

greater than those among Western Australian population pairs, and were statistically significant, while comparisons between Western Australian populations were not significant except for those including Exmouth and 80 Mile Deep. Data for 0+ spat in 1998 and for 1+ spat in 1999 were obtained only from populations within Western Australia and showed no obvious geographical pattern, although the geographically extreme populations of Exmouth and the Lacepedes were significantly different in the $0+$ spat from 1998, and Exmouth was differentiated in the 1+ spat from both 1998 and 1999. Although there was a tendency for the Exmouth and Lacepedes populations to show greater numbers of loci that had statistically significant differences with other populations for $0+$ spat collected in 1998, this trend was not repeated in the 1+ spat collected in 1998 or 1999 (noting that 1+ spat in 1999 are the same recruitment as $0+$ spat in 1998, but are $1 \mathrm{yr}$ older). In addition, the identity of the loci showing the differences changed from year to year (data not shown).

When $F_{\text {ST }}$ analyses were performed over all populations to determine the levels of inter-population differentiation, only 1 locus, Pmx 16_23, had a highly sig- nificant $F_{\mathrm{ST}}$ value in all the datasets for different geographical and age groupings (see Table 3). Additional loci were also significant in the analysis including the Indonesian populations (Pmx 18_21 and Pmx +020), that including all Australian populations (Pmx 18_21) and that of the 0+ spat 1998 samples (Pmx 18_21, Pmx +022 and Pmx 16_05). The overall $F_{\mathrm{ST}}$ values were significant for adult populations only if Darwin (all Australia) or the Indonesian (all Australia + Indonesia) populations were included in the analyses (Table 3). Both these values lost statistical significance when the Pmx 16_23 locus was excluded from the analyses. Values of $N_{\mathrm{e}} m$ indicated high levels of gene flow in most of these analyses, although the estimates from Slatkin's method were about $1 / 3$ to $1 / 5$ those calculated from the overall $F_{\mathrm{ST}}$ values. Data for 1+ spat in 1999 represent a sample of the same cohort as the $0+$ spat collected in 1998, only collected when 1 yr older. Many $F_{\text {ST }}$ values for $1+$ spat in 1999 show reduced values relative to the $0+$ spat in 1998, and a number that were highly significant in 1998 lost significance.

$R_{\mathrm{ST}}$ analyses are based not on allele frequency differences, but on differences in the variances of the sizes of the microsatellite fragments. A similar pattern 
Table 3. Pinctada maxima. $F_{\mathrm{ST}}$ and $R_{\mathrm{ST}}$ values for each locus and overall loci, for analyses overall populations within different datasets denoted by the column headings. ${ }^{*} \mathrm{p}<0.05,{ }^{* *} \mathrm{p}<0.01,{ }^{* * *} \mathrm{p}<0.001$

\begin{tabular}{|c|c|c|c|c|c|c|}
\hline \multirow[t]{2}{*}{ Locus } & \multirow{2}{*}{$\begin{array}{c}\text { All Australia + } \\
\text { Indonesia } \\
\text { Adults }\end{array}$} & \multirow{2}{*}{$\begin{array}{c}\text { All } \\
\text { Australia } \\
\text { Adults }\end{array}$} & \multicolumn{4}{|c|}{ — Western Australia only } \\
\hline & & & Adults & $1+$ spat 1998 & $0+$ spat 1998 & $1+$ spat 1999 \\
\hline \multicolumn{7}{|l|}{$F_{\mathrm{ST}}$} \\
\hline $\operatorname{Pmx}+008$ & 0.0007 & 0.0002 & 0.0002 & 0.0013 & 0.0015 & 0.0027 \\
\hline $\operatorname{Pmx}+014$ & 0.0035 & 0.0029 & 0.0009 & 0.0010 & 0.0080 & $0.0081^{* * *}$ \\
\hline Pmx 18_21 & $0.0070^{*}$ & $0.0084^{* * *}$ & 0.0028 & 0.0005 & $0.0648^{* * *}$ & 0.0010 \\
\hline $\operatorname{Pmx}+020$ & $0.0069^{* *}$ & 0.0027 & 0.0025 & 0.0006 & 0.0146 & 0.0000 \\
\hline $\operatorname{Pmx}+022$ & 0.0026 & -0.0014 & -0.0014 & 0.0018 & $0.0282^{* * *}$ & -0.0001 \\
\hline Pmx 16_05 & 0.0044 & 0.0012 & 0.0005 & 0.0040 & $0.0386^{* * *}$ & 0.0001 \\
\hline Pmx 16_23 & $0.0466^{* * *}$ & $0.0417^{* * *}$ & $0.0186^{* * *}$ & $0.0499^{* * *}$ & $0.1037^{* * *}$ & $0.0332^{* * *}$ \\
\hline Pmx 16_41 & 0.0046 & 0.0004 & -0.0012 & 0.0022 & 0.0042 & -0.0012 \\
\hline Overall & $0.0090^{* * *}$ & $0.0064^{* * *}$ & 0.0025 & $0.0065^{*}$ & $0.0311^{* * *}$ & 0.0045 \\
\hline Excluding Pmx 16_23 & 0.0042 & 0.0002 & 0.0006 & 0.0016 & $0.0233^{* * *}$ & 0.0016 \\
\hline$N_{\mathrm{e}} m$ (all loci) & 75 & 105 & 270 & 104 & 21 & 150 \\
\hline Slatkin's $N_{\mathrm{e}} m$ & 19 & 17 & 17 & 20 & 7 & 15 \\
\hline \multicolumn{7}{|l|}{$R_{\mathrm{ST}}$} \\
\hline Pmx + 014 & $0.0175^{* * *}$ & $0.0160^{* * *}$ & $0.0085^{* * *}$ & -0.0072 & $0.1509^{* * *}$ & $0.0075^{* * *}$ \\
\hline Pmx 18_21 & 0.0011 & 0.0033 & -0.0043 & 0.0038 & $0.2218^{* * *}$ & -0.0025 \\
\hline $\operatorname{Pmx}+020$ & $0.0114^{* * *}$ & $0.0128^{* * *}$ & $0.0149^{* * *}$ & -0.0073 & 0.0109 & -0.0023 \\
\hline Pmx + 022 & $0.0203^{* * *}$ & 0.0006 & 0.0025 & 0.0004 & $0.0532^{* * *}$ & -0.0012 \\
\hline Pmx 16_05 & $0.0123^{* * *}$ & 0.0025 & 0.0007 & $0.0151^{* * *}$ & $0.0172^{*}$ & 0.0023 \\
\hline Pmx 16_23 & $0.0596^{* * *}$ & $0.0498^{* * *}$ & $0.0309^{* * *}$ & $0.0237^{* * *}$ & 0.0131 & $0.0089^{* * *}$ \\
\hline Pmx 16_41 & $0.0081^{* * *}$ & -0.0035 & -0.0048 & $0.0216^{* * *}$ & -0.0132 & -0.0020 \\
\hline Overall & $0.0160^{* * *}$ & $0.0104^{* * *}$ & 0.0053 & 0.0060 & $0.0741^{* * *}$ & 0.0018 \\
\hline Excluding Pmx 16_23 & $0.0113^{* * *}$ & $0.0062^{* *}$ & 0.0027 & 0.0042 & $0.0798^{* * *}$ & 0.0011 \\
\hline$N_{\mathrm{e}} m$ (all loci) & 42 & 65 & 127 & 112 & 9 & 376 \\
\hline
\end{tabular}

of genetic connectivity was observed in those analyses, where Pmx 16_23 had a highly significant $R_{\mathrm{ST}}$ value in all datasets except 0+ spat 1998, but additional loci were also significant in the analysis including the Indonesian populations (all except Pmx 18_21), that including all Australian adult populations $(\mathrm{Pmx}+014$ and Pmx +020$)$ and that of the 0+ spat 1998 samples (Pmx +014, Pmx +022 and Pmx 18_21) (Table 3). Other individual loci had statistically significant $R_{\mathrm{ST}}$ values in the analyses although the overall $R_{\mathrm{ST}}$ value was not significant. Thus, the overall $R_{\mathrm{ST}}$ values were significant for adult populations only if Darwin (all Australia) or the Indonesian (all Australia + Indonesia) populations were included in the analyses. In contrast to the $F_{\mathrm{ST}}$ analyses, none of the $R_{\mathrm{ST}}$ values lost statistical significance when the Pmx 16_23 locus was excluded from the analyses (Table 3 ). Once again, the $0+$ spat 1998 were highly significant, but samples of the same cohort $1 \mathrm{yr}$ later (1+ spat 1999) showed reduced $R_{\mathrm{ST}}$ values that were not statistically significant.

Hierarchical analyses of variance demonstrated that most of the variation occurred within populations $(98.4 \%)$, much of the rest among regions, i.e. Indonesia versus Australia (1.13\%), and very little among populations within regions $(0.68 \%)$. All components were statistically significant (data not shown).

\section{Analysis of isolation by distance}

Graphs of pairwise $F_{\text {ST }}$ plotted as a function of the geographical separation of the populations demonstrated increasing genetic differentiation with increasing geographic separation for Australian populations. This pattern was observed in data from the adult populations and 1+ spat collected in 1998, but only when the Darwin population was included (Fig. 3). The significance of the relationship between genetic differentiation and geographical separation remained after the exclusion of the Pmx 16_23 locus for the adult populations, but not for $1+$ spat collected in 1998 (Table 4). In the case of the adult populations from Western Australia, the overall $F_{\mathrm{ST}}$ value moved from being marginally non-significant to significant after the exclusion of Pmx 16_23. No significant relationship was observed for data from 0+ spat in 1998 or from 1+ spat in 1999.

When the Indonesian data were included in the analysis, these fit the pattern of isolation by distance for $F_{\mathrm{ST}}$, whether adults only were used or whether all data for the Australian populations ('pooled' in Fig. 4, top 2 graphs) were used. The significant relationship remained, whether or not Pmx 16_23 was excluded from the analysis (Table 4). Analyses of $R_{\mathrm{ST}}$ showed the Indonesian populations formed a cluster above the Australian data points, with $R_{\mathrm{ST}}$ values greater than 

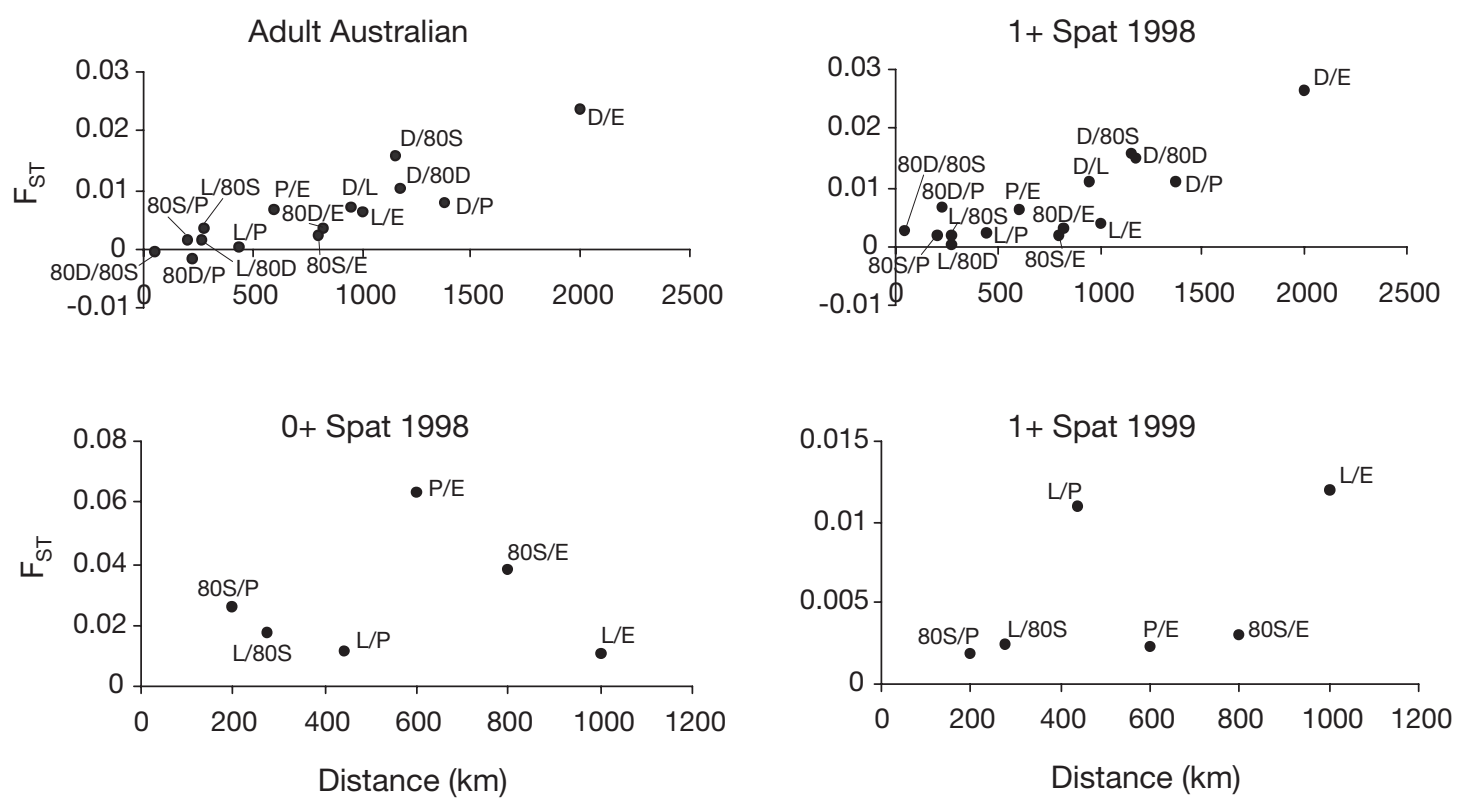

Fig. 3. Pinctada maxima. $F_{\mathrm{ST}}$ as a function of geographical separation of population pairs for Australian populations of adults (Mantel test $\mathrm{p}=0.054), 1+$ spat collected in $1998(\mathrm{p}=0.044), 0+$ spat collected in $1998(\mathrm{p}=0.678)$ and 1+ spat collected in 1999 $(p=0.135)$. Population abbreviations: D: Darwin; L: Lacepede Islands; 80D: 80 Mile Beach Deep; 80S: 80 Mile Beach Shallow; P: Port Hedland; E: Exmouth Gulf

expected on the basis of their geographical separation from Australian populations. The theoretical basis for $R_{\mathrm{ST}}$ assumes a stepwise model for change in microsatellite allele size, which is violated in compound microsatellites. When the analyses were repeated excluding Pmx +008 , there was no essential change to the $F_{\mathrm{ST}}$ or $R_{\mathrm{ST}}$ plots (data not shown).

The overall spatial patterns of relationships are summarized in terms of the extent of gene flow among population pairs (Fig. 5) demonstrating high gene flow among Western Australian populations, lower gene flow among these and Indonesian populations and intermediate connectivity with Northern Territory.

\section{Comparison of different year-classes}

Allele frequencies differed between particular recruitment cohorts and their adult populations, at up to 6 loci in the case of $0+$ spat 1998 from the 80 Mile Shallow population, but differentiation over all loci (measured by $F_{\mathrm{ST}}$ ) was not significant in any of the comparisons (data not shown). There was also no consistency in the identity of the loci that showed significant differences in allele frequency from the adult population, either among different populations, or among recruitment cohorts (or different age groups of the same cohort) from the same location.

When comparisons were made of recruitments from particular years, using similarly aged spat, no significant differences over all loci were found, nor was there any consistency in the identity of individual loci that were found to have significant differences in allele frequencies between recruitment events (data not shown). The degrees of genetic differentiation were similar when comparisons were made between recruit-

Table 4. Pinctada maxima. Probability values from the Mantel test for various datasets denoted by column headings. A significant value following Bonferroni correction (Rice 1989) for multiple tests (in bold) indicates a positive relationship of genetic differentiation with geographic separation of populations

\begin{tabular}{|c|c|c|c|c|c|c|}
\hline \multirow[t]{2}{*}{ Locus } & \multirow{2}{*}{$\begin{array}{c}\text { All Australia + } \\
\text { Indonesia } \\
\text { Adults }\end{array}$} & \multirow{2}{*}{$\begin{array}{c}\text { All } \\
\text { Australia } \\
\text { Adults }\end{array}$} & \multicolumn{4}{|c|}{ Western Australia only } \\
\hline & & & Adults & $\begin{array}{c}1+\text { spat } \\
1998\end{array}$ & $\begin{array}{c}0+\text { spat } \\
1998\end{array}$ & $\begin{array}{c}1+\text { spat } \\
1999\end{array}$ \\
\hline \multicolumn{7}{|l|}{$F_{\mathrm{ST}}$} \\
\hline All loci & 0.001 & 0.010 & 0.054 & 0.044 & 0.678 & 0.135 \\
\hline $\begin{array}{l}\text { Excluding } \\
\text { Pmx 16_23 }\end{array}$ & 0.001 & 0.017 & 0.040 & 0.653 & - & - \\
\hline \multicolumn{7}{|l|}{$\boldsymbol{R}_{\mathrm{ST}}$} \\
\hline All loci ${ }^{\mathrm{a}}$ & 0.006 & 0.092 & 0.284 & 0.050 & 0.657 & 0.322 \\
\hline $\begin{array}{l}\text { Excluding } \\
\text { Pmx 16_23 }\end{array}$ & 0.009 & 0.106 & 0.269 & 0.066 & 0.692 & 0.511 \\
\hline${ }^{\mathrm{a}}$ Excluding + & 008 compound & d locus & & & & \\
\hline
\end{tabular}




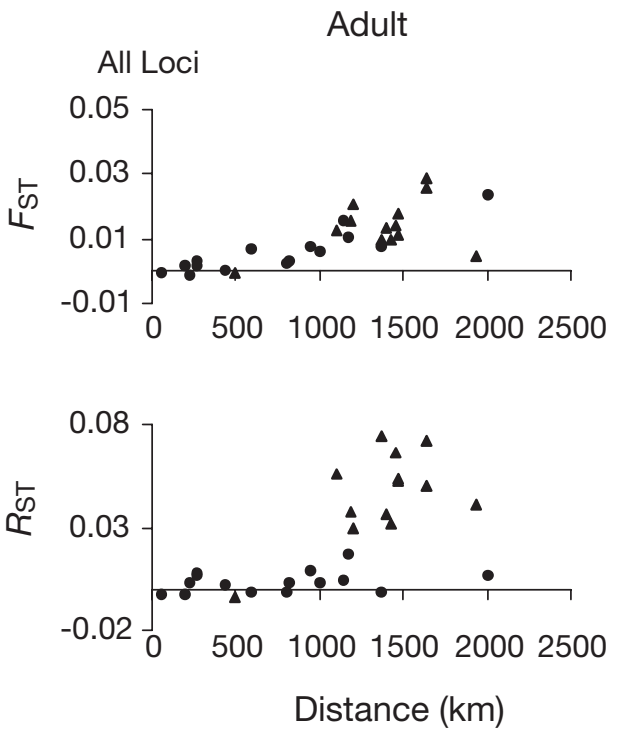

Pooled
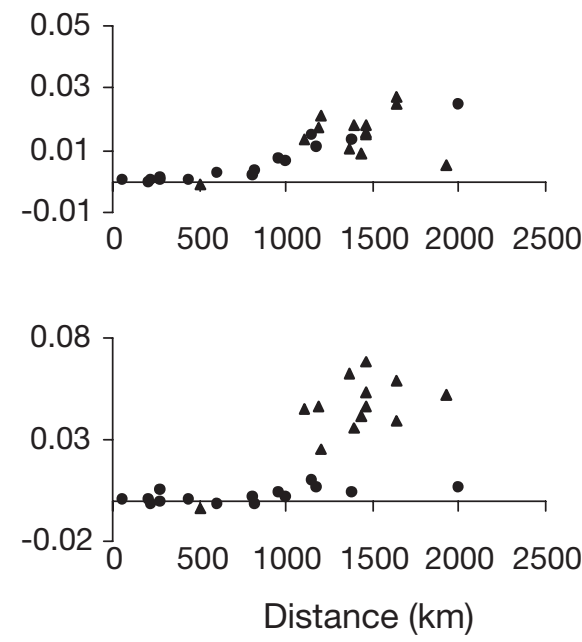

Fig. 4. Pinctada maxima. $F_{\mathrm{ST}}$ and $R_{\mathrm{ST}}$ graphed as functions of geographical separation of population pairs, using only adults (adult) or samples in which the different age-classes were pooled with the adult populations (pooled). Comparisons with Indonesian populations have been given a different symbol (triangles). The single comparison between populations within Indonesia is the triangle near the $x$-axis at $\sim 500 \mathrm{~km}$. Mantel test p-value for the adult $F_{\mathrm{ST}}$ is 0.001 and for $R_{\mathrm{ST}}$ is 0.006

ment groups in which differences in age also existed between samples. The levels of genetic differentiation were also similar when comparing different ageclasses of the same recruitment group (that occurring in 1998). In all cases there was no consistent pattern of

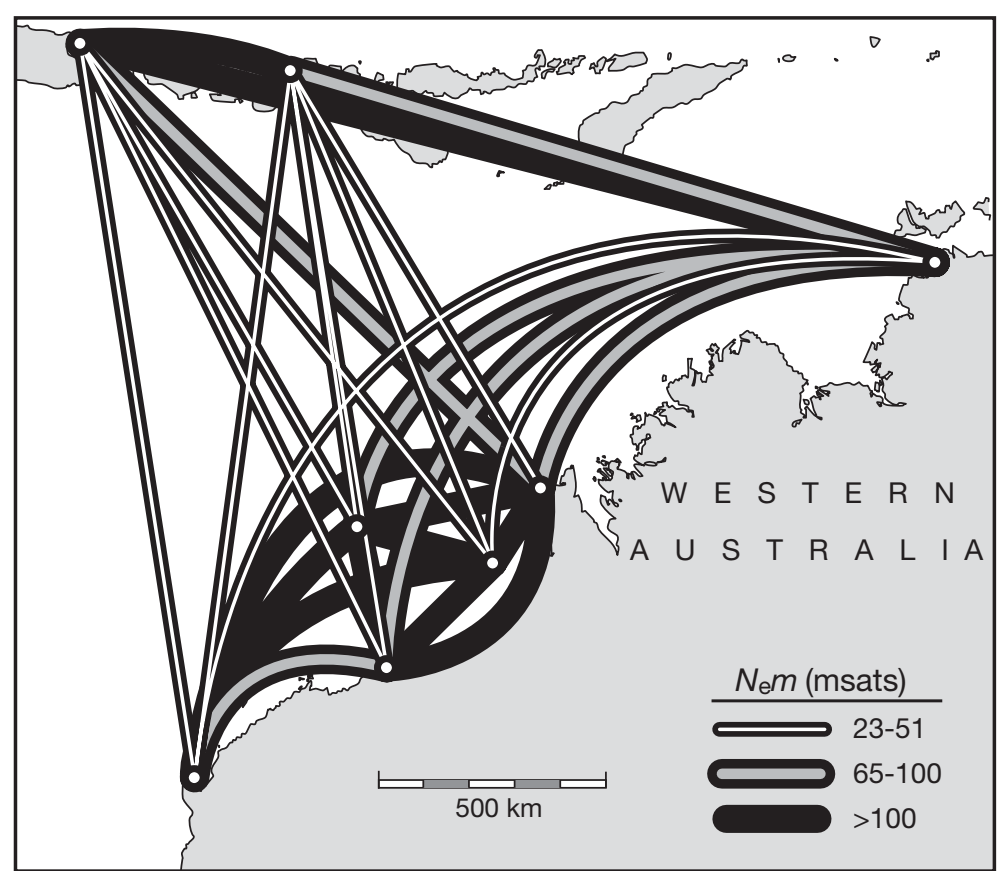

Fig. 5. Pinctada maxima. Summary illustrations of the levels of gene flow $\left(N_{\mathrm{e}} m\right.$, average no. of migrants per generation) between populations estimated from 8 microsatellite loci identity of loci that showed significant differences in allele frequencies. Of the 4 populations in which some comparisons were possible, most had only 1 or 2 loci that showed significant differences between recruitment or between age-classes. The 80 Mile Shallow population showed several such loci, and values of $F_{\mathrm{ST}}$ an order of magnitude greater than the other populations (albeit not significantly different from 0). However, even in the 80 Mile Shallow population, large differences were observed between age-classes of the same recruitment cohort, between the 1998 and 1999 recruitment events and in cases where there was an age and cohort difference.

\section{Estimation of effective population size}

Effective population sizes for each of the populations sampled were estimated from the mean assuming a mutation rate of $\mu=10^{-4}$ (Table 5). The likely extremes in $N_{\mathrm{e}} m$ were calculated by taking the lower $95 \%$ confidence limit and assuming a high mutation rate $\left(\mu=10^{-3}\right)$ and the higher 95\% confidence limit and assuming a low mutation rate $\left(\mu=10^{-5}\right)$. The higher long-term effective population size estimates were all greater than several 100000 s, and all the lowest estimates 
Table 5. Pinctada maxima. Estimates of the effective population sizes $\left(N_{\mathrm{e}}\right)$ for each of the populations sampled

\begin{tabular}{|c|c|c|c|c|c|}
\hline & $\begin{array}{c}4 N_{\mathrm{e}} \mu \\
\text { Mean } \\
\text { (upper-lower } \\
95 \% \mathrm{CL} \text { ) }\end{array}$ & $\begin{array}{c}\text { Lowest estimate } \\
\text { (lower CL, } \\
\mu=10^{-3} \text { ) }\end{array}$ & $\begin{array}{c}\text { Estimate from } \\
\text { the mean } \\
\left(4 N_{\mathrm{e}} \mu, \mu=10^{-4}\right)\end{array}$ & $\begin{array}{l}\text { Highest estimate } \\
\text { (upper CL, } \\
\mu=10^{-5} \text { ) }\end{array}$ & $\begin{array}{c}N_{\mathrm{e}} \text { from } N_{\mathrm{k}} \\
\text { in 1+ spat } \\
\text { Mean (upper-lower } \\
95 \% \mathrm{CL} \text { ) }\end{array}$ \\
\hline Madura & $10.02(4.88-27.57)$ & 1220 & 25048 & 689250 & - \\
\hline Sumbawa & $8.38(3.76-26.77)$ & 940 & 20947 & 669250 & - \\
\hline Darwin & $9.39(4.75-32.33)$ & 1188 & 23474 & 808250 & - \\
\hline Lacepedes & $8.07(4.92-37.46)$ & 1230 & 20176 & 936500 & 23 (9-infinity) \\
\hline 80 Mile Deep & $7.54(2.77-36.04)$ & 693 & 18845 & 901000 & - \\
\hline 80 Mile Shallow & $6.99(2.09-31.25)$ & 523 & 17480 & 781250 & $179(92-3280)$ \\
\hline Port Hedland & $8.62(4.26-30.25)$ & 1065 & 21539 & 756250 & $111(61-645)$ \\
\hline Exmouth & $6.06(1.54-42.47)$ & 385 & 15152 & 1061750 & 204 (86-infinity) \\
\hline
\end{tabular}

were $>300$. Calculations based on the variance in gene frequencies in different generations using data from 1+ spat indicated a mid-range value of 100 to 200 parents contributed to the recruits in each generation for all populations except the Lacepedes, which had an order of magnitude less. However, the $95 \%$ confidence limits of these estimates were large, ranging from several 10s of individuals to infinity. While the Lacepedes had a lower value of 9 individuals for the long-term effective population size, the upper confidence limit was infinity.

\section{DISCUSSION}

\section{Spatial population structure}

Previous work by Johnson \& Joll (1993) found evidence of clinal variation in allozyme variants between populations of Pinctada maxima from the western, northern and eastern coastlines of Australia. They found statistically significant differences between each of the population pairs they examined, except for the 2 Western Australian populations sampled, Exmouth Gulf and Cape Bossut (included in the present survey as part of the 80 Mile Deep sample). The present study has provided more detailed information within Western Australia. A clear signature of isolation by distance was observed between Exmouth Gulf and Darwin. This was found whether adult populations resulting from several recruitment events or whether juveniles representing the recruitment for only $1 \mathrm{yr}$ were analyzed.

Within Western Australia, the results usually indicated no overall population differentiation. The results of pairwise comparisons of populations suggested, however, that those populations at the extremes of the Western Australian range (Lacepedes in the north and Exmouth Gulf in the south) differed significantly in some allele frequencies. These findings are consistent with the relative geographical isolation of the Exmouth population in a gulf largely separated from the open ocean and of the small Lacepedes populations situated on relatively isolated islands. Pinctada maxima found in Exmouth also have a slightly different shell shape than those from elsewhere on the coast, although the extent to which this results from genetic differences, as opposed to different environments within the gulf, is unknown.

Recently, spat falls in Exmouth Gulf have been reduced to a far greater degree than at other sites in Western Australia, leading to concern that the source of recruits to this population might be different to that of other sites. The results here suggest that this population may be more isolated than others and that it may have a greater degree of self-recruitment. Although many pairwise $F_{\mathrm{ST}}$ values between Exmouth Gulf and the other Western Australian sites were statistically significant, levels of gene flow were still high. In summary, the microsatellite markers detected significant spatial differences in the genetic constitution of Pinctada maxima populations when populations were included in the analyses that were in different biogeographical zones (e.g. Indonesia) or were a great distance away (e.g. Northern Territory). Hierarchical analysis of population differentiation indicated significant between-region differentiation and significant differences among populations within regions.

Both $F_{\mathrm{ST}}$ and $R_{\mathrm{ST}}$ analyses provided similar results in that they both showed a pattern of isolation by distance. However the $R_{\mathrm{ST}}$ data demonstrated a greater difference between Indonesian and Australian populations than expected on the basis of their geographical separation. $F_{\mathrm{ST}}$ is particularly influenced by differences in the frequency of genetic variants among populations. $R_{\mathrm{ST}}$ is based on the variance in the size of the microsatellite markers in different populations. Since it takes longer for mutations to change the size distribution after populations are separated, it has been argued that $F_{\mathrm{ST}}$ is more reliable than $R_{\mathrm{ST}}$ at 
detecting recent population structure. This is because migration and genetic drift will be more influential than mutational events over short time periods (Wenburg et al. 1998). Since $R_{\mathrm{ST}}$ takes longer to reach equilibrium than $F_{\mathrm{ST}}$, estimates of $R_{\mathrm{ST}}$ are likely to reflect older relationships between populations. The results of the present study suggest greater historical isolation of the Indonesian populations from the Australian ones than among Australian populations. No genetic differentiation among any of the Australian populations, but a marked difference between Indonesian and Australian populations, was observed in an analysis of Pinctada maxima mtDNA (Benzie et al. 2003). This study provided estimates of times of divergence of Indonesian and Australian populations of $>100000$ yr. The nuclear data provide consistent, though less clear cut, results, and suggest no largescale, direct exchange between Indonesian and Western Australian populations.

There have been a number of studies of genetic variation in a variety of marine species across northern Australia and over the Indo-Pacific that provide a more general framework against which to interpret the Pinctada maxima data (Benzie 1999a). Firstly, data from organisms as diverse as mangroves (Duke et al. 1998), seastars (Williams \& Benzie 1997, 1998, Benzie 1999b) and prawns (Benzie et al. 2002) have shown marked genetic differences between Indian and Pacific Ocean populations, but a close association between Western Australian populations and Pacific rather than Indian Ocean populations (see Williams \& Benzie 1998 for a chart of ocean circulation in the region). Using mtDNA markers, Western Australian populations of prawns were demonstrated to be most closely connected to northern Australian populations rather than Indonesian populations (Benzie et al. 2002). Data from P. maxima mtDNA suggest the same pattern as the prawns (Benzie et al. 2003). Although the currents of the Indonesian throughflow move southward between the Indonesian Islands, they are strongly deflected westwards just south of the Indonesian arc and do not appear to reach the coastal regions of Australia (see Williams \& Benzie 1998). The genetic evidence from a variety of species suggests little or no direct gene exchange with Western Australian populations. The present results show $P$. maxima has limited genetic differentiation at small geographical scales, isolation by distance at larger scales and additional differentiation between populations separated by biogeographical boundaries.

The pearling industry has moved stock from Western Australia to the Northern Territory, but there is no indication that this has homogenized wild Pinctada maxima populations. Johnson \& Joll (1993) noted marked genetic difference between Western Australian popu- lations and those from Oxley Island in the Northern Territory. This was the case despite large numbers of Western Australian animals having been introduced to a farm within $80 \mathrm{~km}$ of Oxley Island. The only other published study pertinent to the impact of cultured stock on the genetic structure of wild pearl oyster populations concerns P. margaritifera. That study showed no impact of extensive pearl farming on the genetic structure of wild populations (Arnaud et al. 2003c).

\section{Temporal variation}

Temporal shifts in microsatellite frequencies or genetic variation between age-classes might indicate selection, or the occurrence of recruits from genetically different sources. No such patterns were observed in the Pinctada maxima data. The occasional shifts in gene frequencies between cohorts suggested these effects were the result of localized heterogeneity in the genetic constitution of recruits resulting from large variance in the local reproductive success of particular matings. The effects of the inbreeding resulting from these processes have been well described for the oyster Crassostrea gigas (McGoldrick \& Hedgecock 1997), and their effects in a wild population have been demonstrated in detailed studies of the clam Spisula ovalis (David et al. 1997b).

\section{Within-population variation}

Genetic variation was high in all populations, but significant deficits of heterozygotes were observed in most populations at several loci. Heterozygote deficits are commonly observed in marine shellfish (Berger 1983, Zouros \& Pogson 1994), and have been reported in the previous allozyme studies of Pinctada maxima (Johnson \& Joll 1993). It has been postulated that heterozygote deficits can be explained by differential selection of genotypes at different stages in the life cycle (Durand \& Blanc 1989), temporal heterogeneity in the genetic constitution of recruits as demonstrated in limpets (Johnson \& Black 1984), assortative mating of genotypes possibly as a result of different times of spawning (Smith 1987, Ríos et al. 1996), or null alleles (Zouros \& Foltz 1984). Durand \& Blanc (1989) were able to demonstrate that the heterozygote deficits they observed in $P$. margaritifera were not the result of selection at particular loci. No evidence of postsettlement selection was observed in the present study. Evidence for null alleles was found at the appropriate loci within all populations showing a heterozygote deficit for those loci, with the exception of Pmx +008 at the Lacepedes. It is likely that null alleles were respon- 
sible at least in part for these heterozygote deficits. In the other cases, the deficits observed may be the result of stochastic levels of inbreeding resulting from variance in reproductive success and the genetic identity of the subset of individuals contributing to a given cohort (David et al. 1997b, McGoldrick \& Hedgecock 1997).

\section{Effective population size}

Estimates of the short-term effective population sizes determined from variation in allele frequencies in $1+$ spat settled in different years had large variances, but indicated that 100 to 200 parents contributed to the recruits in each generation for all populations except the Lacepedes, which had an order of magnitude less. The upper $95 \%$ confidence limits of these estimates were large, ranging from several 10s to 1000 s and up to infinity. These results are similar to estimates obtained for several natural populations of each of 2 oyster species in North America (Hedgecock et al. 1992). These data are also consistent with estimates of the long-term effective population sizes gained from the Pinctada maxima microsatellite data. The lowest estimates were $>300$ and suggest little inbreeding within populations. These data are consistent with the high genetic exchange among populations detected in the spatial analysis.

\section{CONCLUSIONS}

The ability to link short-term demographic changes and genetic data to improve the use of the latter data for population management requires extensive modeling (Taylor \& Dizon 1996, Taylor et al. 2000). However, the Pinctada maxima data have allowed an assessment of the geographic range of dispersal and short-term dynamics of recruitment in a tropical mollusc. They indicate extensive gene flow among Western Australian populations that suggests no need to manage the stocks separately, but the strong pattern of isolation by distance suggests the level of genetic exchange is reduced over larger spatial scales. The fluctuations in gene frequencies observed from one generation to the next appear to result from stochastic effects resulting from high variance in reproductive success. These results do not indicate major shifts in the geographic source of recruits, or the effect of selection as previously reported in detailed studies of the clam Spisula ovalis (David et al. 1997b) and of Crassostrea gigas (McGoldrick \& Hedgecock 1997). Assessing short-term fluctuations in recruitment on ecological time scales, known to exist among the Western Australian popula- tions, will be best managed through tracking annual spat fall using standard demographic methods. Recent analysis of past recruitment data has shown that, while recruitment varies over time, only the 80 Mile Beach area, with widespread populations of $P$. maxima in shallow and deep water, gives consistent spat recruitment (K. Friedman, FRDC project 1998/153, pers. comm.). Recruitment is much less reliable in other areas with good spat fall in 1 yr supplying recruits for several years.

Acknowledgements. We thank the staff, skippers and crew of Arrow Pearling Company, Broome Pearls, Maxima Pearling Company, Morgan and Co. Pty Ltd, Norwest Pearling, Paspaley Pearling Co., Pearl Coast Divers Pty Ltd., The Gun Charter Fishing and the Pearl Producer's Association, Helen O'Donogahue and officers from Western Australian Fisheries and Northern Territory Fisheries for their assistance. We also thank the staff of the Gondol Fisheries Research Centre of the Indonesian Government, particularly Dr. Ketut Sugama, Dr. Haryanti and Sari Budi Moria, and E. Ballment and S. Uthicke from AIMS, for their collaboration in sampling pearl oysters from Indonesia. We thank Megan Johnson, Lesa Peplow, Christine Clegg and Melissa Merrit for technical assistance, and Lee Ann Rollins for assistance with statistical analysis of the results. In part this work made use of the bioinformatics facilities of the Australian National Genomic Information Service (ANGIS).

\section{LITERATURE CITED}

Adamkewicz SL, Harasewych MG (1996) Systematics and biogeography of the genus Donax (Bivalvia: Donacidae) in eastern North America. Am Malacol Bull 13:97-103

Arnaud S, Monteforte M, Galtier N, Bonhomme F, Blanc F (2001) Population structure and genetic variability of pearl oyster Pinctada mazatlantica along Pacific coasts from Mexico to Panama. Conserv Genet 1:299-307

Arnaud-Haond S, Monteforte $\mathrm{M}$, Blanc $\mathrm{F}$, Bonhomme $\mathrm{F}$ (2003a) Evidence for male-biased effective sex ratio and recent step-by-step colonization in the bivalve Pinctada mazatlantica. J Evol Biol 16:790-796

Arnaud-Haond S, Bonhomme F, Blanc F (2003b) Large discrepancies in differentiation of allozymes, nuclear and mitochondrial DNA loci in recently founded Pacific populations of the pearl oyster Pinctada margaritifera. J Evol Biol 16:388-398

Arnaud-Haond S, Vonau V, Bonhomme F, Boudry P, Prou J, Seaman T, Veyret M, Goyard E (2003c) Spat collection of the pearl oyster (Pinctada margaritifera cumingii) in French Polynesia: an evaluation of the potential impact on genetic variability of wild and farmed populations after 20 years of commercial exploitation. Aquaculture 219: 181-192

Beaumont AR, Khamdan SAA (1991) Electrophoretic and morphometric characters in population differentiation of the pearl oyster Pinctada radiata (Leach), from around Bahrain. J Molluscan Stud 57:433-441

Benzie JAH (1999a) Genetic structure of coral reef organisms - ghosts of dispersal past. Am Zool 39:131-145

Benzie JAH (1999b) Major genetic differences between crown-of-thorns starfish (Acanthaster planci) populations from the Indian and Pacific Oceans. Evolution 53: 1782-1795 
Benzie JAH, Ballment E (1994) Genetic differences among black-lipped pearl oyster (Pinctada margaritifera) populations in the western Pacific. Aquaculture 127:145-156

Benzie JAH, Ballment E, Forbes AT, Demetriades NT, Sugama K, Haryanti, Moria S (2002) Mitochondrial DNA variation in Indo-Pacific populations of the giant tiger prawn, Penaeus monodon. Mol Ecol 11:2553-2569

Benzie JAH, Smith C, Sugama K (2003) Mitochondrial DNA reveals genetic differentiation between Australian and Indonesian pearl oyster Pinctada maxima (Jameson, 1901) populations. J Shellfish Res 22: 781-787

Berger M (1983) Population genetics of marine gastropods and bivalves. In: Russel-Hunter WDD (ed) The Mollusca, Vol 6. Academic Press, New York, p 563-595

Brookfield JFY (1996) A simple new method for estimating null allele frequency from heterozygote deficiency. Mol Ecol 5(3):453-455

Caffey HM (1985) Spatial and temporal variation in settlement and recruitment of intertidal barnacles. Ecol Monogr 55:313-332

Connell JH, Keough MJ (1985) Disturbance and patch dynamics of subtidal marine animals on hard substrata. In: Pickett STA, White PS (eds) The ecology of natural disturbance and patch dynamics. Academic Press, Orlando, FL, p $125-151$

Crow JF, Aoki K (1982) Group selection for a polygenic behavioural trait: a differential proliferation model. Proc Natl Acad Sci USA 79:2628-2631

Crow JF, Aoki K (1984) Group selection for a polygenic behavioural trait: estimating the degree of population subdivision. Proc Natl Acad Sci USA 81:6073-6077

Crow JF, Kimura M (1970) An introduction to population genetics theory. Harper \& Row, New York

Cruz P, Ramirez JL, Garcia GA, Ibarra AM (1998) Genetic differences between two populations of catarina scallop ( $\mathrm{Ar}$ gopecten ventricosus) for adaptations for growth and survival in a stressful environment. Aquaculture 166:321-335

David P, Jarne P (1997) Context-dependent survival differences among electrophoretic genotypes in natural populations of the marine bivalve Spisula ovalis. Genetics 146: 335-344

David P, Delay B, Berthou P, Jarne P (1995) Alternative models for allozyme associated heterosis in the marine bivalve Spisula ovalis. Genetics 139:1719-1726

David P, Delay B, Jarne P (1997a) Heterozygosity and growth in the marine bivalve Spisula ovalis: testing alternative hypotheses. Genet Res Camb 70:215-223

David P, Perdieu M, Pernot A, Jarne P (1997b) Fine-grained spatial and temporal population genetic structure in the marine bivalve Spisula ovalis. Evolution 51:1318-1322

David P, Berthou P, Noel P, Jarne P (1997c) Patchy recruitment patterns in marine invertebrates: a spatial test of the density-dependent hypothesis in the bivalve Spisula ovalis. Oecologia 111:331-340

Duke N, Benzie JAH, Goodall JA, Ballment E (1998) Genetic structure and evolution of species in the mangrove genus Avicennia (Avicenniaceae) in the Indo-Pacific. Evolution 52:1612-1626

Durand P, Blanc F (1986) Divergence génétique chez un bivalve marin tropical: Pinctada margaritifera. In: Biologie des populations, Coll. Natl., CNRS. Université Claude Bernard, Lyons, p 323-330

Durand P, Blanc F (1989) Diversité génétique chez un bivalve marin tropical: Pinctada margaritifera (Linné, 1758). Bull Soc Zool Fr 113:293-304

Excoffier L, Smouse P, Quattro J (1992) Analysis of molecular variance inferred from metric distances among DNA haplotypes: application to human mitochondrial DNA restriction data. Genetics 131:479-491

Fevolden SE (1992) Allozymic variability in the Iceland scallop Chlamys islandica: geographic variation and lack of growth-heterozygosity correlations. Mar Ecol Prog Ser 85:259-268

Galand PE, Fevolden SE (2000) Population structure of Chlamys islandica in the Northeast Atlantic-northern stocks compared with a southern relict population. Sarsia 85:183-188

Gervis MH, Sims NA (1992) The biology and culture of pearl oysters (Bivalvia: Pteriidae). ICLARM Stud Rev 21: 1-49

Hedgecock D, Chow V, Waples RS (1992) Effective population numbers of shellfish broodstocks estimated from temporal variance in allelic frequencies. Aquaculture 108: $215-232$

Johnson MS, Black R (1984) Pattern beneath the chaos: the effect of recruitment on genetic patchiness in an intertidal limpet. Evolution 38:1371-1383

Johnson MS, Joll LM (1993) Genetic subdivision of the pearl oyster Pinctada maxima (Jameson, 1901) (Mollusca : Pteriidae) in northern Australia. Aust J Mar Freshw Res 44: 519-526

Krause MK, Bricelj VM (1995) Gpi genotypic effect on quantitative traits in the northern bay scallop, Argopecten irradians irradians. Mar Biol 123:511-522

Lenfant P, Planes S (2002) Temporal genetic changes between cohorts in a natural population of a marine fish, Diplodus sargus. Biol J Linn Soc 76:9-20

Lewis RI, Thorpe JP (1994) Temporal stability of gene frequencies within genetically heterogeneous populations of the queen scallop Aequipecten (Chlamys) opercularis. Mar Biol 121:117-126

Mantel N (1967) The detection of disease clustering and a generalised regression approach. Cancer Res 27:209-220

McGoldrick DJ, Hedgecock D (1997) Fixation, segregation and linkage in allozyme loci in inbred families of the Pacific oyster Crassostrea gigas (Thunberg): implications for the causes of inbreeding depression. Genetics 146: 321-334

Menge BA (1991) Relative importance of recruitment and other causes of variation in rocky intertidal community structure. J Exp Mar Biol Ecol 146:69-100

Pollak E (1983) A new method for estimating the effective population size from allele frequency changes. Genetics 104:531-548

Raymond M, Rousset F (1995) GENPOP, Ver 3.1. Institut des Sciences de l'Evolution, Université de Montpellier

Rice WR (1989) Analysing tables of statistical tests. Evolution 43:223-225

Ríos C, Canales J, Peña JB (1996) Genotype dependent spawning: evidence from a wild population of Pecten jacobaeus (L.) (Bivalvia: Pectinidae). J Shellfish Res 15: 645-651

Ryman N, Utter F (eds) (1987) Population genetics and fishery management. University of Washington Press, Seattle, WA

Sambrook J, Fritsch EF, Maniatis T (1989) Molecular cloning: a laboratory manual, 2nd edn. Cold Spring Harbor Laboratory Press, Cold Spring Harbor, NY

Schneider S, Kueffer JM, Roessli D, Excoffier L (2000) ARLEQUIN manual, Ver 2.0. A software for population genetic analysis. Genetics and Biometry Laboratory, University of Geneva

Shirai S (1994) Pearls and pearl oysters of the world. Marine Planning Company, Okinawa

Slatkin M (1995) A measure of population subdivision based on microsatellite allele frequencies. Genetics 139:457-462 
Smith C, Benzie JAH, Wilson KJ (2003) Isolation and characterisation of eight microsatellite loci from silverlipped pearl oyster Pinctada maxima. Mol Ecol Notes 3: 125-127

Smith PJ (1987) Homozygote excess in the flounder, Rhombosolea plebeia, produced by assortative mating. Mar Biol 95:489-492

Taylor BL, Dizon AE (1996) The need to estimate power to link genetics and demography for conservation. Conserv Biol 10:661-664

Taylor BL, Chivers SJ, Sexton S, Dizon AE (2000) Evaluating dispersal estimates using mtDNA data: comparing analytical and simulation approaches. Conserv Biol 14: $1287-1297$

van Oosterhout C, Hutchinson WF, Willis DPM, Shipley PF (2004) Micro-checker Version 2.2.1. Available from www.microchecker.hull.ac.uk

Volckaert F, Zouros E (1989) Allozyme and physiological variation in the scallop Placopecten magellanicus and a general model for the effects of heterozygosity on fitness in marine molluscs. Mar Biol 103:51-61

Wada KT (1982) Inter- and intraspecific electrophoretic variation in three species of the pearl oysters from the Nansei Islands of Japan. Bull Natl Res Inst Aquac (Jpn) 3:1-10

Waples RS (1991) Genetic methods for estimating the effective population size of cetacean populations. In: Hoelzel

Editorial responsibility: Otto Kinne (Editor-in-Chief), Oldendorf/Luhe, Germany
AR (ed) Genetic ecology of whales and dolphins. Spec. Issue No. 13, International Whaling Commission, Cambridge, p 279-300

Weber JL, Wong C (1993) Mutation of human short tandem repeats. Hum Mol Genet 2:1123-1128

Weir BS, Cockerham SS (1984) Estimating F-statistics for the analysis of population structure. Evolution 38:1358-1370

Wenburg JK, Bentzen P, Foote CJ (1998) Microsatellite analysis of genetic population structure in an endangered salmonid: the coastal cutthroat trout (Oncorhynchus clarki). Mol Ecol 7:733-749

Williams ST, Benzie JAH (1997) Indo-West Pacific patterns of genetic differentiation in the high-dispersal starfish Linckia laevigata. Mol Ecol 6:559-573

Williams ST, Benzie JAH (1998) Evidence of a biogeographic break between populations of a high dispersal starfish: congruent regions within the Indo-West Pacific defined by colour morphs, mtDNA and allozyme data. Evolution 52: 87-99

Zouros E, Foltz DW (1984) Possible explanations of heterozygote deficiency in bivalve mollusks. Malacologia 25: 583-591

Zouros E, Pogson GH (1994) Heterozygosity, heterosis and adaptation. In: Beaumont AR (ed) Genetics and evolution of aquatic organisms. Chapman \& Hall, London, p $135-146$

Submitted: January 6, 2003; Accepted: October 20, 2005 Proofs received from author(s): March 30, 2006 